\title{
TINDAK TUTUR KONSTANTIF DALAM INTERAKSI TOKOH FILM SUARA DARI PESISIR YANG DISUTRADARAI OLEH SUSILO RAHARJO DAN IMPLIKASINYA DALAM PEMBELAJARAN
}

\author{
Supriyati, Herman Didipu, Muslimin \\ Magister Pendidikan Bahasa Indonesia, Pascasarjana Universitas Negeri Gorontalo
}

\begin{abstract}
ABSTRAK
Tujuan penelitian ini yaitu (1) mendeskripsikan jenis tindak tutur konstantif dalam interaksi tokoh film Suara dari Pesisir disutradarai oleh Susilo Raharjo, (2) mendeskripsikan fungsi tindak tutur konstantif dalam interaksi tokoh film Suara dari Pesisir yang disutradarai oleh Susilo Raharjo, (3) mendeskripsikan implikasi tindak tutur konstantif dalam interaksi film Suara dari Pesisir pada pembelajaran di sekolah. Metode yang digunakan dalam penelitian ini yaitu metode kualitatif. Prosedur penelitian dilakukan secara bertahap, mulai dari tahap persiapan, tahap analisis data, dan tahap akhir. Teknik pengumpulan data yang digunakan dalam penelitian ini adalah teknik Simak Bebas Libat Cakap (SBLC). Teknik analisis data yang digunakan adalah teknik pilah unsur penentu (PUP) sebagai teknik dasar dan teknik hubung banding menyamakan (HBS) sebagai teknik lanjutan. Adapun metode yang digunakan yaitu metode padan referensial dan metode padan pragmatis. Berdasarkan penelitian yang telah dilakukan, peneliti menemukan 12 jenis tindak tutur konstantif, yaitu tindak tutur asertif, tindak tutur prediktif, tindak tutur deskriptif, tindak tutur informatif, tindak tutur konfirmatif, tindak tutur konsesif, tindak tutur retraktif, tindak tutur asentif, tindaka tutur dissentif, tindak tutur disputative, tindak tutur responsif, dan tindak tutur sugestif. Fungsi tindak tutur konstantif yang ditemukan dalam penelitian ini sebanyak 39 data. Jenis tindak tutur yang paling banyak digunakan dalam film Suara dari Pesisir adalah tindak tutur responsive dengan fungsi menjawab yaitu sebanyak 9 data. Penelitian ini memiliki implikasi (keterkaitan) dengan kegiatan pembelajaran di sekolah. Film dapat dijadikan media pembelajaran Bahasa Indonesia di sekolah, khususnya di tingkat SMP kelas VIII semester genap. Sebagai media pembelajaran, film dan transkrip film dapat diimplikasikan pada kegiatan belajar KD 3.12. menelaah struktur dan kebahasaan teks ulasan (film, cerpen, puisi, novel, dan karya seni daerah) yang diperdengarkan dan dibaca. KD 4.12 menyajikan tanggapan tentang kualitas karya (film, cerpen, puisi, novel, karya seni daerah, dll) dalam jenis teks ulasan secara lisan dan tulis dengan memperhatikan struktur, unsur kebahasaan, atau aspek lisan.
\end{abstract}

Kata kunci: Tindak Tutur Konstantif, Film, Impikasi Pembelajaran

\section{PENDAHULUAN}

Diantara semua makhluk ciptaan Tuhan, manusialah makhluk Tuhan yang paling sempurna. Menurut Markhamah, dkk (2009:1), manusia adalah makhluk yang berbudaya. Sebagai makhluk yang berbudaya, manusia dianugerahi alat komunikasi yang tidak dimiliki makhluk lain yaitu bahasa. Bahasa dipahami sebagai media komunikasi atau alat interaksi. Chaer (2010:15) mengatakan bahwa bahasa digunakan oleh penuturnya untuk berkomunikasi atau berinteraksi dalam suatu tuturan. Sebagai alat komunikasi, maka manusia tidak akan lepas dari tuturan yang diucapkan untuk melakukan percakapan dengan orang lain sebagai wujud interaksinya. Komunikasi bukan hanya sekedar penyampaian bahasa melalui kata-kata melainkan selalu disertai dengan perilaku atau tindakan. Tindakan manusia ketika mengucapkan tuturan atau ujaran disebut dengan tindak tutur.

Tindak tutur merupakan perwujudan dari fungsi bahasa. Yule (2006:82-83) mengemukakan tindak tutur adalah suatu tindakan yang ditampilkan lewat tuturan. Tindak tutur dibagi menjadi tiga yaitu tindak 
lokusi (locutionary acts), tindak ilokusi (illocutionary acts), dan tindak perlokusi (perlocutionary acts). Tindak tutur lokusi merupakan jenis tuturan kalimat dengan makna yang mudah dipahami. Tindak tutur ilokusi merupakan tindak mengucapkan suatu pernyataan, tawaran, janji, dan peringatan yang dilakukan penutur dalam pengucapan kalimat. Tindak tutur perlokusi menghasilkan efek yang ditimbulkan oleh suatu tuturan atau pengucapan sesuatu, seperti kekaguman, himbauan, dan bujukan. Ibrahim (1993:14) menyebutkan keempat jenis tindak ilokusi yaitu konstantif, direktif, komisif, dan acknowledgments. Dalam penelitian ini, peneliti memfokuskan penelitian pada tindak tutur konstantif.

Tindak tutur konstantif merupakan ekspresi kepercayaan yang dibarengi dengan ekspresi maksud sehingga mitra tutur memegang kepercayaan yang serupa. Selain dalam percakapan sehari-hari, tindak tutur juga dapat ditemui dalam sebuah karya sastra berjenis cerpen, novel, drama, maupun film. Film bisa berperan sebagai komunikasi bahasa. Film merupakan gambaran kehidupan nyata yang dimunculkan dalam bentuk tontonan. Film mempunyai sifat multi fungsi, selain sebagai jenis hiburan, film juga merupakan media komunikasi untuk menyampaikan pesan yang diwujudkan dalam bentuk tindak tutur. Tindak tutur dalam film tentunya memiliki makna. Makna tuturan-tuturan tersebut dapat dikaji dalam bidang ilmu pragmatik. Pragmatik adalah studi tentang makna yang disampaikan oleh penutur dan ditafsirkan oleh mitra tutur. Hal serupa juga dikemukakan oleh Emaliana \& Perdhani (2013:2), pragmatic is the field of linguistics that examines how language is used in interaction (pragmatik adalah bidang linguistik yang meneliti bagaimana bahasa digunakan dalam interaksi). Pada penelitian ini, peneliti menggunakan film sebagai sumber data penelitian. Pemilihan film Suara dari Pesisir disutradarai oleh Susilo Raharjo sebagai objek penelitian dengan mempertimbangkan tema film yang dirasa sering dialami dalam kehidupan sehari-hari terutama dalam dunia pendidikan.

\section{METODE PENELITIAN}

Penelitian ini merupakan penelitian dokumentasi berupa film. Penelitian tindak tutur konstantif dalam interaksi tokoh film Suara dari Pesisir Disutradarai oleh Susilo Raharjo ini merupakan penelitian kualitatif. Penelitian kualitatif disebut juga penelitian naturalistik karena meneliti kondisi obyek yang alamiah. Hal ini sesuai dengan yang dikemukakan oleh Djajasudarma (1993:8), bahwa metode penelitian deskriptif adalah metode yang bertujuan membuat deskripsi, maksudnya membuat gambaran, lukisan secara sistematis, faktual dan akurat mengenai data, sifat-sifat serta hubungan fenomena-fenomena yang diteliti. Jenis penelitian yang digunakan yaitu studi naratif. Selain sebagai pengumpul data, peneliti juga bertindak sebagai instrumen penelitian. Dalam penelitian ini digunakan dua jenis data, yaitu data primer dan data sekunder. Data primer dalam penelitian ini yaitu tindak tutur konstantif dalam interaksi tokoh film Suara dari Pesisir yang telah ditranskripkan ke dalam jenis tulisan. Menurut Arikunto (2014:172), Sumber data adalah subjek darimana data dapat diperoleh. Adapun sumber data dalam penelitian ini adalah film Suara dari Pesisir Disutradarai oleh Susilo Raharjo. Penelitian ini menggunakan metode simak. Teknik pengumpulan data yang digunakan adalah teknik Simak Bebas Libat Baca atau lebih dikenal dengan singkatan SBLC. Teknik SBLC dilakukan dengan menyadap tanpa perlu berpartisipasi bekerja (Zaim,2014:90). Penelitian tindak tutur konstantif dalam interaksi tokoh film Suara dari Pesisir Disutradarai oleh Susilo Raharjo ini menggunakan metode padan untuk menganalisis data. Penelitian ini menggunakan metode padan referensial dan metode padan pragmatis untuk mendeskripsikan jenis dan fungsi dari setiap tindak tutur konstantif yang terdapat dalam film Suara dari Pesisir disutradarai oleh Susilo Raharjo. Dalam penerapannya, peneliti menggunakan teknik pilah unsur penentu (PUP) sebagai teknik dasar dan teknik hubung banding menyamakan (HBS) sebagai teknik lanjutan. 


\section{HASIL PENELITIAN DAN PEMBAHASAN}

Menurut jenis dan fungsinya, tindak tutur konstantif yang terdapat dalam interaksi tokoh film Suara dari Pesisir disutradarai oleh Susilo Raharjo terdiri dari 1). tindak asertif (fungsimenyatakan, menunjukkan, mempertahankan, dan menyampaikan, 2). tindak prediktif (fungsi memprediksi), 3). tindak deskriptif (fungsi mendeskripsikan dan menghargai), 4). tindak informatif (f ung si menginformasikan, melaporkan dan menasehati) 5). tindak konfirmatif (fungsi menilai dan menyimpulkan) 6). tindak konsesif (fungsi mengakui dan mengizinkan), 7). tindak retraktif (fungsi membantah) 8). tindak asentif (fungsi menerima dan menyetujui). 9) tindak dissentif (fungsi tidak setuju). 10) tindak disputatif (fungsi berkeberatan) 11). tindak responsif (fungsi menjawab dan fungsi merespon), 12). tindak sugestif ( $\mathrm{fungsi}$ me ny ara $\mathrm{k}$ a n dan menebak).

\section{A. Tindak Tutur Deskriptif dengan Fungsi Mendeskripsikan}

Tindak tutur konstantif jenis deskriptif yang berfungsi mendeskripsikan terdapat pada data (16) berikut ini.

\section{Bonco : Indonesia keren! (00:09:57)}

Tuturan (fungsi16) diucapkan Bonco saat mengagumi keindahan pulau Labengki. Pantai yang berpasir putih, laut yang menyerupai pulau Ampat di Papua, serta air laut yang berbeda warna. Ia begitu kagum, sehingga meneriakkan kata "Indonesia keren".

Konteks tuturan (16) berdasarkan delapan komponen tutur SPEAKING terdiri dari setting, yaitu di tepi pantai. Participants, yaitu penutur dan mitra tutur. Bonco bertindak sebagai penutur dan Bajo bertindak sebagai mitra tutur. Ends (maksud dan tujuan) tuturan Bonco adalah mendeskripsikan keindahan Pulau Labengki. Act (bentuk dan isi tuturan) yaitu bentuk tuturan mendeskripsikan. Act (intonasi nada) yang digunakan oleh penutur adalah suara keras dan panjang. Instrumentalities (jalur Bahasa) yaitu bahasa lisan, karena langsung diucapkan saat melihat keindahan alam yang dimaksud. Norms (norma) yang berlaku dalam tuturan ini yaitu norma kesusilaan. Norma tersebut berlaku karena penutur dengan jujur mengakui bahwa alam Indonesia sangat indah. Genre (bentuk penyampaian) tuturan ini berbentuk ungkapan.

Berdasarkan konteks dari tuturan (16), maksud dan tujuan dari tuturan tersebut adalah mendeskripsikan keindahan alam Indonesia. Hal tersebut didukung oleh reaksi penutur yang kagum akan keindahan Pulau Labengki. Begitu pula reaksi Bajo saat Bonco mengatakan bahwa Indonesia keren, ia ikut tersenyum. Dengan mempertimbangkan konteks tuturan berdasarkan kedelapan komponen tutur SPEAKING dan reaksi mitra tutur, maka tuturan (16) termasuk tindak tutur jenis deskriptif yang berfungsi untuk mendeskripsikan.

\section{B. Tindak tutur informative dengan Fungsi Menasehati}

Tindak tutur informatif yang berfungsi menasehati terdapat pada tuturan (05) berikut ini.

\section{Ibu guru : nah, ini bajunya harus dikasih masuk. (00:03:34)}

Tuturan (05) disampaikan oleh ibu guru saat berbaris di lapangan. Ketika seluruh siswa berbaris di lapangan, ibu guru memeriksa kerapian seragam yang dikenakan siswa.

Berdasarkan konteks tutur, tuturan (05) sudah memenuhi syarat tindak tutur sesuai pendapat Austin. Maksud dan tujuan dari tuturan tersebut adalah untuk menasehati seluruh siswa agar mematuhi aturan di sekolah, misalnya aturan berpakaian. Hal tersebut didukung oleh reaksi mitra tutur yang tersenyum menyadari kesalahannya dan langsung mengikuti perintah gurunya. Dengan mempertimbangkan konteks sebuah tuturan berdasarkan komponen SPEAKING dan reaksi mitra tutur, maka tuturan (05) termasuk tindak tutur konstantif jenis informatif yang berfungsi menasehati.

\section{Tindak Tutur Retraktif dengan Fungsi Membantah \\ Tindak tutur jenis retraktif dengan fungsi membantah terdapat pada data tuturan (11) berikut ini.}


Bapak : sekolahmu itu sudah cukup. Kau mau belajar apalagi?

Bajo : belum cukup pak. Bajo masih mau melanjutkan sekolah. (00:07:27)

Tuturan (11) disampaikan Bajo saat baru pulang dari rumah gurunya. Bapaknya tidak mengizinkan Bajo melanjutkan sekolah dengan mengatakan bahwa sekolah Bajo sudah cukup. Namun Bajo mengatakan bahwa sekolahnya belum cukup, karena dia masih ingin melanjutkan sekolah.

Berdasarkan konteks tutur SPEAKING, tuturan (11) sudah memenuhi konteks tutur tersebut. Berdasarkan konteks tutur, maksud dan tujuan dari tuturan tersebut adalah Bajo tidak setuju dengan ucapan bapaknya yang mengatakan bahwa sekolahnya sudah cukup, dengan artian tidak perlu melanjutkan sekolah lagi, namun Bajo masih ingin melanjutkan sekolah, sehingga ia membantah ucapan bapak sebelumnya. Reaksi yang muncul dari mitra tutur ketika mendengar ucapan Bajo yaitu memandang Bajo dan langsung menghentikan perdebatan dengan menyuruh Bajo untuk membersihkan ikan. Dengan mempertimbangkan konteks sebuah tuturan berdasarkan komponen tutur SPEAKING dan reaksi mitra tutur, maka tuturan (11) termasuk tuturan jenis retraktif dengan fungsi membantah.

\section{Implikasi Film dalam Pembelajaran}

Film dapat dijadikan media pembelajaran Bahasa Indonesia di sekolah, khususnya di tingkat SMP kelas VIII semester genap. Sebagai media pembelajaran, film dan transkrip film dapat diimplikasikan pada kegiatan belajar KD 3.12. menelaah struktur dan kebahasaan teks ulasan (film, cerpen, puisi, novel, dan karya seni daerah) yang diperdengarkan dan dibaca. KD 4.12 menyajikan tanggapan tentang kualitas karya (film, cerpen, puisi, novel, karya seni daerah, dll) dalam jenis teks ulasan secara lisan dan tulis dengan memperhatikan struktur, unsur kebahasaan, atau aspek lisan.

\section{KESIMPULAN}

Berdasarkan hasil penelitian dan pembahasan, maka peneliti menyimpulkan bahwa sebagian besar jenis tindak tutur konstantif terdapat pada interaksi tokoh film Suara dari Pesisir disutradarai oleh Susilo Raharjo. Jenis-jenis dan fungsi tindak tutur konstantif tersebut adalah 1). tindak asertif (fungsi menyatakan, menunjukkan, mempertahankan, dan menyampaikan, 2). tindak prediktif (fungsi memprediksi), 3). tindak deskriptif (fungsi mendeskripsikan dan menghargai), 4). tindak informatif (f ung si menginformasikan, melaporkan dan menasehati) 5). tindak konfirmatif (fungsi menilai dan menyimpulkan) 6). tindak konsesif (fungsi mengakui dan mengizinkan), 7). tindak retraktif (fungsi membantah) 8). tindak asentif (fungsi menerima dan menyetujui). 9) tindak dissentif (fungsi tidak setuju). 10) tindak disputatif (fungsi berkeberatan) 11). tindak responsif (fungsi menjawab dan fungsi merespon), 12). tindak sugestif (fungsi menyarankandan menebak). Selain itu, film dapat diimplikasikan ke dalam pembelajaran di tingkat SMP khususnya kelas VIII semester genap pada KD 3.12. menelaah struktur dan kebahasaan teks ulasan (film, cerpen, puisi, novel, dan karya seni daerah) yang diperdengarkan dan dibaca. KD 4.12 menyajikan tanggapan tentang kualitas karya (film, cerpen, puisi, novel, karya seni daerah, dll) dalam jenis teks ulasan secara lisan dan tulis dengan memperhatikan struktur, unsur kebahasaan, atau aspek lisan.

\section{DAFTAR PUSTAKA}

Arikunto, Suharsimi. 2014. Prosedur Penelitian. Jakarta: PT. Rineka Cipta

Chaer, Abdul. 2010. Sosiolinguistik : Perkenalan Awal. Jakarta : PT. Rineka Cipta

Djajasudarma, T. Fatimah. 1993. Metode Linguistik. Bandung: PT. Eresco

Emaliana, Ive \& Widya Caterina Perdhani. 2013. Pragmatics in Language 
Learning. Malang: Universitas

Brawijaya Press

Ibrahim, Abd. Syukur. 1993. Kajian Tindak Tutur. Surabaya: Usaha Nasional

Markhamah, dkk. 2009. Analisis Kesalahan dan Kesantunan Berbahasa. Surakarta: Muhammadiyah University Press

Yule, George. 2006. Pragmatik. Yogyakarta: Pustaka Pelajar.

Zaim, M. 2014. Metode Penelitian Bahasa: Pendekatan Struktural. Padang: FBS UNP Press 